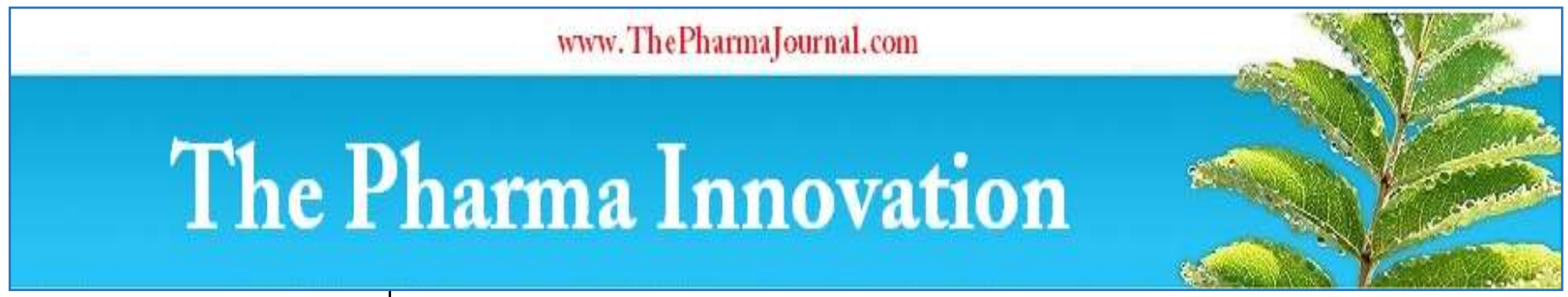

ISSN (E): 2277 - 7695

ISSN (P): 2349-8242

NAAS Rating: 5.23

TPI 2021; 10(3): 839-850

(C) 2021 TPI

www.thepharmajournal.com

Received: 02-01-2021

Accepted: 06-02-2021

Shivani Ranjan

Department of Agronomy, Bihar Agricultural University, Sabour, Bhagalpur, Bihar, India

Sumit Sow

Department of Agronomy, Bihar Agricultural University, Sabour, Bhagalpur, Bihar, India
Corresponding Author:

Shivani Ranjan

Department of Agronomy, Bihar Agricultural University, Sabour, Bhagalpur, Bihar, India

\title{
Phytoremediation: An eco-friendly approach towards clean and green future
}

\section{Shivani Ranjan and Sumit Sow}

DOI: https://doi.org/10.22271/tpi.2021.v10.i31.5890

\begin{abstract}
Soil contamination with toxic metals resulting from global industrialization is a serious environmental issue. Industrial activities such as mining of ore, discharge of wastewater, excess application of fertilizer and pesticide application have led to contamination of environment with heavy metals such as cadmium, lead, mercury, copper, arsenic, copper, zinc etc. Complete degradation of heavy metals is not possible and thus they continuously accumulate in the environment leading to great threat to life on the earth. Many human health risks are associated with the entry of heavy metals in the food chain. Thus, remediation of heavy metals from contaminated sites is essential to reduce the negative impact of toxic metals to ensure a safe environment for future generation. Conventional techniques involve use of chemicals for cleaning contaminated sites which reduces productivity of soil. Phytoremediation is an emerging technology that uses green plants to clean up or remove the contaminants from the environment. It is known by various names such as agro-remediation, green remediation, vegetative remediation, green technology and botano remediation. It involves several mechanisms such as phytoaccumulation, phytostabilization, phytovolatilization and phytodegradation. Phytoremediation is a cost effective, socially acceptable and environment friendly technology for decontaminating heavy metal polluted sites. It is important to raise awareness of this technology to enhance its acceptability as a global sustainable technology.
\end{abstract}

Keywords: Heavy metals, phytoremediation, soil contamination

\section{Introduction}

Heavy metals are elements with a specific gravity at least 5 times that of water. Arsenic, chromium, copper, lead, mercury, cadmium are some of the heavy metals that are toxic and tends to accumulate in the food chain. Heavy metals are obtained either from natural and anthropogenic sources. Naturally, heavy metals are associated with the volcanic eruption, wind erosion, forest fire and use of fossil fuel. The metals from the natural sources have less negative impact on the environment in general, whereas the metals from anthropogenic sources such as smelters, thermal power plants, mines, is a threat to mankind (Nagajyoti et al., 2010) ${ }^{[16]}$. Heavy metals such as lead, mercury, arsenic, copper, zinc and cadmium are highly poisonous when they enter into the biological system through food chain (Misra and Gedamu, 1989) ${ }^{[13]}$. Hence, remediation of heavy metals from contaminated sites is important. There is a need for technologies to remediate contaminated lands. Phytoremediation has gained attention over the recent decades, as a rising and eco-friendly approach that utilizes the natural abilities of plants to remediate contaminated environment. The term phytoremediation refers to the use of green plants to minimize the toxic effects of potential contaminant in the environment. Plants are unique organisms that have unique metabolic and absorption capabilities, and transport system that can take up nutrients or contaminants selectively from the soil or water. This technique can be used for remediation of heavy metals from soil and is found economically feasible and efficient approach in comparison to the engineering techniques such as soil incineration, soil washing, flushing, solidification etc. (Ali et al., 2013; Wang et al., 2015) ${ }^{[1,24]}$.

\section{Mechanisms of phytoremediation}

There are four mechanism of phytoremediation that are involved in remediation of the contaminated sites:
i. Phytodegradation
ii. Phytovolatilization
iii. Phytoaccumulation 
iv. Phytostabilization

\section{Phytodegrdation}

Phytodegradation is the process of breakdown of contaminants by enzymes into more simple or less-toxic products by plants either in the rhizosphere before their uptake or in the root after their uptake subsequently by further synthesis. It is also known as phytotransformation. Breakdown of contaminants occurs in two ways that is either through metabolic process inside the plant or through enzymes produced by the plant. If phytodegradation occurs in the rhizosphere, the required enzymes such as dehalogenase and oxygenase are released from the roots of plants. However, if degradation takes place within the plants, it is important that the plant should be able to uptake the contaminants and translocate them to the place of transformation in their original form, without any negative impact on the plant cells. The factors affecting the process of phytodegradation includes pollutants uptake efficiency, its concentration in the soil and the water present in the ground. There is a wide range of contaminants that can be metabolized, including herbicides, insecticides, pesticides, chlorinated solvents, munitions, and inorganic compounds (Gerhardt et al., 2009) ${ }^{[6]}$. Vetiveria zizanioides plants were capable to clean up $97 \%$ of TNT (trinitrotoluene) from the soil by producing nitroreductase enzyme (Das et al., 2010) ${ }^{[3]}$. On the other hand, Nicotiana tabacum contributed to the degradation of TNT (trinitrotoluene) through nitroreductase enzyme produced by roots (Hannink et al., 2007) ${ }^{[8]}$.

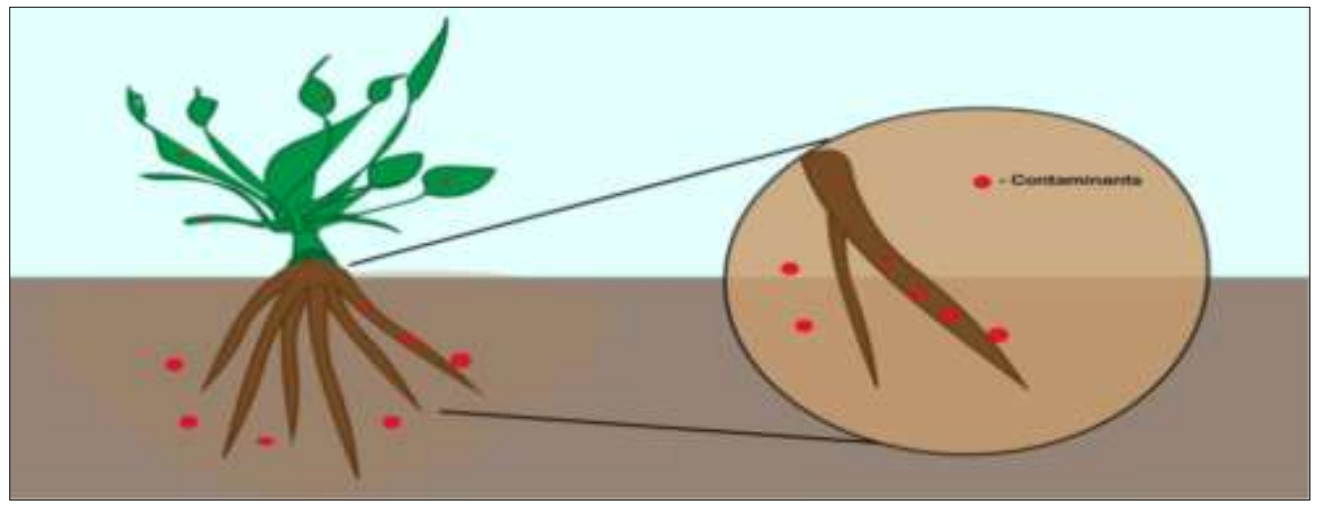

Fig 1: Phytodegradation (Muthusaravanan et al., 2018) ${ }^{[15]}$

Table 1: Various plants reported for phytodegradation and the metals contaminants removed by them

\begin{tabular}{|c|c|c|}
\hline Plants & Contaminants & References \\
\hline Pteris vittata, & Arsenic & Sakakibara et al. $(2010)$ \\
\hline Liriodendron tulipifera & Mercury & Greipsson (2011) \\
\hline Brassica juncea & Mercury & Moreno et al. (2004) \\
\hline
\end{tabular}

\section{Phytovolatilization}

Phytovolatilization is the process of uptake of pollutants and converts it to less toxic volatile forms. In this process, the pollutants are assimilated by the roots, translocated to the shoot and volatized in atmosphere through the stomatal leaves. It is based on the mechanism of evapotranspiration and mainly used for $\mathrm{Hg}$, Se, and organic solvent contamination (Karami and Shamsuddin, 2010) ${ }^{[9]}$. The contaminants are converted into volatile forms such as dimethyl selenide and mercuric oxide by the plants and further evaporated or volatilized into the atmosphere (Fig. 4).
The volatile forms of $\mathrm{Hg}$ and $\mathrm{Se}$ are still toxic to living system, so this remains as a controversial technique for remediation of heavy metals.

Phytovolatilization can be considered as permanent site solution because the gaseous volatilized products are highly unlikely to redeposit at or near the site. Inorganic selenium substances found in the soil are more toxic than its volatile forms (Terry et al. 2000) ${ }^{[23]}$. Table number represents different plants used for phytovolatilization and the metals contaminants removed by them.

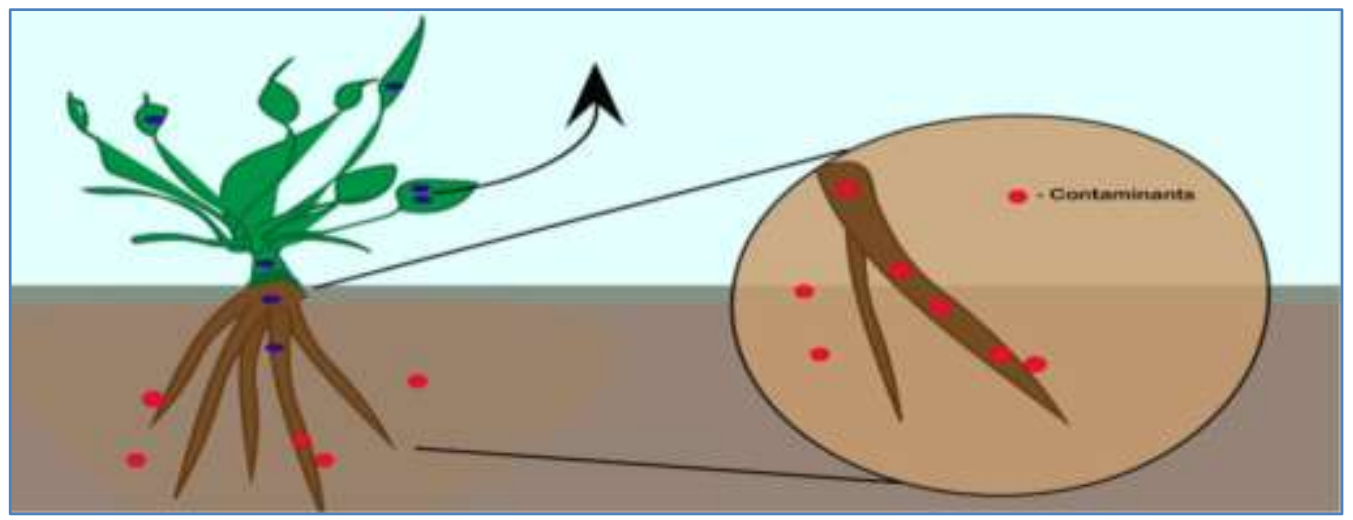

Fig 2: Phytovolatilization (Muthusaravanan et al., 2018) ${ }^{[15]}$ 
Table 2: Various plants reported for phytovolatilization and the metals contaminants removed by them

\begin{tabular}{|c|c|c|}
\hline Plants & Contaminants & References \\
\hline Trifolium repens & $\mathrm{Cd}, \mathrm{Zn}$ and $\mathrm{Pb}$ & Bidar et al. $(2006)$ \\
\hline Cynodon dactylon & $\mathrm{Cd}, \mathrm{Zn}$ and $\mathrm{Pb}$ & Yang et al. $(2014)$ \\
\hline Populus tremula & $\mathrm{Cd}$ and Ni & Brunner et al. (2008) \\
\hline Lupinus uncinatus & $\mathrm{Cd}$ & Ehsan et al. (2009) \\
\hline
\end{tabular}

from contaminated soil but it was found more suitable for the

\section{Phytoaccumulation}

Phytoaccumulation is the process in which the plants absorb the contaminants from contaminated sites as well as other nutrients and water required for their growth. The absorbed contaminants are not destroyed but gets accumulated in shoots, leaves and other parts of the plant. It is also called as phytoextraction. The ability of plants to uptake heavy metals from contaminated soil and accumulate them within themselves to a higher level without signs of toxicity is called hyperaccumulation. Aquatic plant species such as Eichhornia crassipes and Centella asiatica have been reported for their ability to accumulate different concentrations of copper from the contaminated sites (Mokhtar et al., 2011) ${ }^{[14]}$. Cyperus rotundus was utilized to remove chromium and cadmium removal of chromium than cadmium from contaminated sites

(Subhasini and Swamy, 2014) ${ }^{[21]}$. The exact reason behind this unique ability of hyperaccumulation by plants is still not clear but the defense mechanism could be a possible reason behind it. As per the latest research, these plants are protecting themselves from different pathogens or herbivores by accumulating hazardous materials in their tissues which are poisonous in nature. The metal accumulation by hyperaccumulators depends on factors such as metal bioavailability within the rhizosphere, rate of metal uptake by roots, rate of translocation to shoots and cellular tolerance to toxic metals (Etim, 2012) ${ }^{[5]}$.

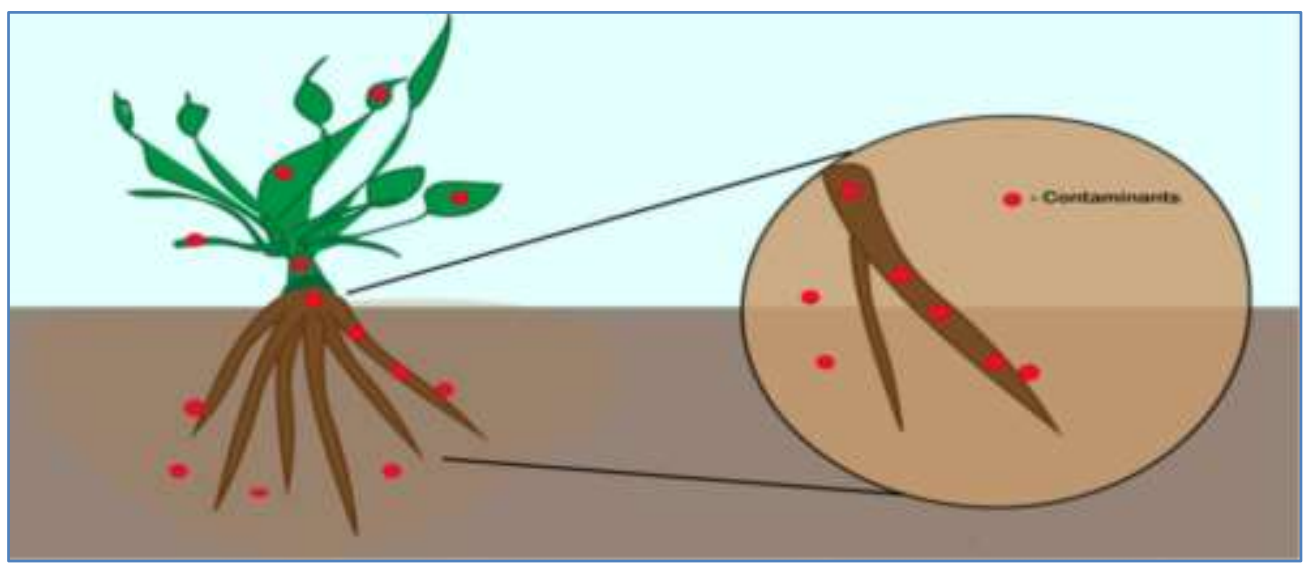

Fig 3: Phytoaccumulation (Muthusaravanan et al. 2018) ${ }^{[15]}$

Table 3: Plant species involved in phytoaccumulation and their site of accumulation

\begin{tabular}{|c|c|c|c|}
\hline Plants & Contaminants & Site of accumulation & References \\
\hline Colocasia esculenta & $\mathrm{As}$ & Leaves & Mains et al. $(2006)$ \\
\hline Brassica juncea & $\mathrm{Ni}$ & Shoots & Saraswat and Rai (2009) \\
\hline Pteris vittata & $\mathrm{As}$ & Roots & Kalve et al. (2011) \\
\hline
\end{tabular}

\section{Phytostabilization}

Phytostabilization is a process in which plant species immobilize contaminants at contaminated sites by accumulating them in the roots through root hairs, adsorption onto root surface, or precipitation within the rhizosphere of certain plant species (Mendez and Maier, 2008) ${ }^{[12]}$. This process limits the movement of the contaminants, prevents its entry into the food chain and eventually reduces its bioavailability. Since, phytostabilization apprehend the contaminants within the root zones of the plants and prevents its entry into the vegetative parts, this method can help to reestablish vegetation at contaminated sites with high metal concentrations where the natural vegetation is not possible (Regvar et al., 2006). The metal-tolerant plant species can be employed as phytostabilizers to restrict the movement of various contaminants by wind, rain or leaching of contaminants into the groundwater. The plant-associated micro-biota in phytostabilization such as Novosphingobium, Variovorax, Streptomyces, Amycolatopsis, and Pseudomonas reduces the metal absorption or mobilization to higher vegetative parts by limiting the metal bioavailability in the rhizosphere itself. The process involves various special mechanisms to immobilize or to inactivate the metal adsorption in plants. The mechanisms for heavy metal resistance in microbes are as follows: (1) prevent metal entry by a permeability barrier or active expulsion of metal outside the cell; (2) detoxification where metal is chemically modified to its less active forms (Rouch et al., 1995) ${ }^{[19]}$. This method prevents the entry of contaminants into nearby ground and surface water sources. However, this method had notable limitations such as contaminant remaining in the soil. 


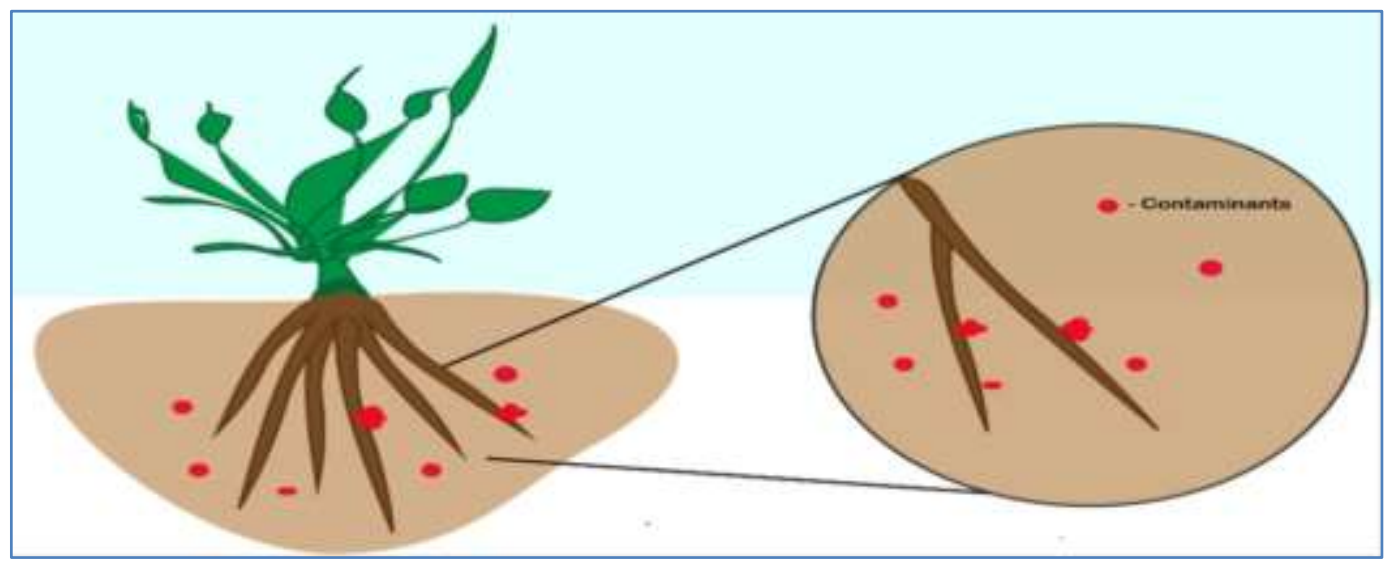

Fig 4: Phytostabilization (Muthusaravanan et al., 2018) ${ }^{[15]}$

Table 4: Various plants used for phytostabilization and the metals contaminants removed by them

\begin{tabular}{|c|c|c|}
\hline Plants & Contaminants & References \\
\hline Clerodendrum indicum & $\mathrm{Fe}$ & Mukherjee et al. (2013) \\
\hline Nicotiana tabacum Vetiveria zizanioides & $\mathrm{Pb}$ & Boonyapookana et al. $(2005)$ \\
\hline Riccinus Communis & $\mathrm{Ni}$ & Adhikari and Kumar (2012) \\
\hline Wolffia globose & $\mathrm{Cr}$ & Boonyapookana et al. (2002) \\
\hline
\end{tabular}

\section{Selection criteria of plant species for phytoremediation}

The plant species should be adapted to local climates, depth of the plant's root should be favourable to uptake the contaminants, ability of the species to flourish in the type of soil present, ability to extract or degrade the concerned contaminants to less toxic form, fast growth rate, susceptible to genetic manipulation, ease of planting and maintenance and the uptake of large amount of water by evapotranspiration. Care should be taken into consideration during the selection process to prevent the introduction of non-native species into the areas where those species are absent (Cunningham et al., 1995) ${ }^{[2]}$. The plant species which is selected for use at brownfield sites have some maintenance requirements, which includes the intercultural operations, fertilizer requirement, pruning, harvesting and monitoring programs (SasNowosielska et al., 2004).

\section{Phytoremediation of contaminated soil with Helianthus annuus and Macrotyloma uniflorum}

This study was conducted to test the potential of Helianthus annuus and Macrotyloma uniflorum to extract the metal contaminants from the soil. The contaminated soil, containing heavy metals like chromium, cadmium, and lead, was prepared in the laboratory. Plants were grown in the contaminated and controlled soil pots for 28 days, and soil samples were collected every week from each pot and was analysed. The concentration of heavy metal concentrations in soil decrease with the increase in plant growing time in the Helianthus annuus pots (Fig.5). The phytoremediation results of Helianthus annuus (Fig. 5 and 7) indicated that this plant remediates chromium to the greatest extent, lead metal moderately and cadmium to a certain extent. In Fig.6 it is clear that concentration of heavy metal in the soil decreased with the increase in plant growing time in case of Macrotyloma uniflorum. The results of phytoremediation of Macrotyloma uniflorum suggested that this plant has remediated chromium to the greatest extent, lead metal to some extent, and cadmium very little. After the third or fourth week of phytoremediation, the levels of metal ions were determined in the plants. Plants were digested and these samples were then used for the measurement of different metal ions. The missing metal ions from the soil after the phytoremediation were recovered from the plants. Among the three plants, Helianthus annuus showed the maximum remediation of all three contaminated metals $(\mathrm{Cr} 73.86 \%, \mathrm{Cd}$ $42.22 \%$, and $\mathrm{Pb} 61.72 \%$ ), whereas Macrotyloma uniflorum remediated chromium to the maximum extent and the other two heavy metals to a lesser extent. Macrotyloma uniflorum remediated $\mathrm{Cr}, \mathrm{Cd}$, and $\mathrm{Pb}$ to the extent of $71.96 \%, 27.81 \%$, and $37.39 \%$, respectively. From this study, it is very clear that these two plants especially Helianthus annuus can be used effectively for phytoremediation of contaminated soils in a short duration.

Table 5: Heavy metal concentration in soil (Orekanti et al., 2019) ${ }^{[18]}$

\begin{tabular}{|c|c|c|}
\hline Heavy metal & Chemical & Conc. (mg/kg) \\
\hline Chromium $(\mathrm{Cr})$ & Chromium chloride $\left(\mathrm{CrCl}_{2}\right)$ & 388.63 \\
\hline Cadmium $(\mathrm{Cd})$ & Cadmium nitrate $\left(\mathrm{CdNO}_{3}\right)$ & 96.53 \\
\hline Lead $(\mathrm{Pb})$ & Lead acetate $\left[\mathrm{Pb}\left(\mathrm{CH}_{3} \mathrm{COO}\right)_{2}\right]$ & 965.30 \\
\hline
\end{tabular}




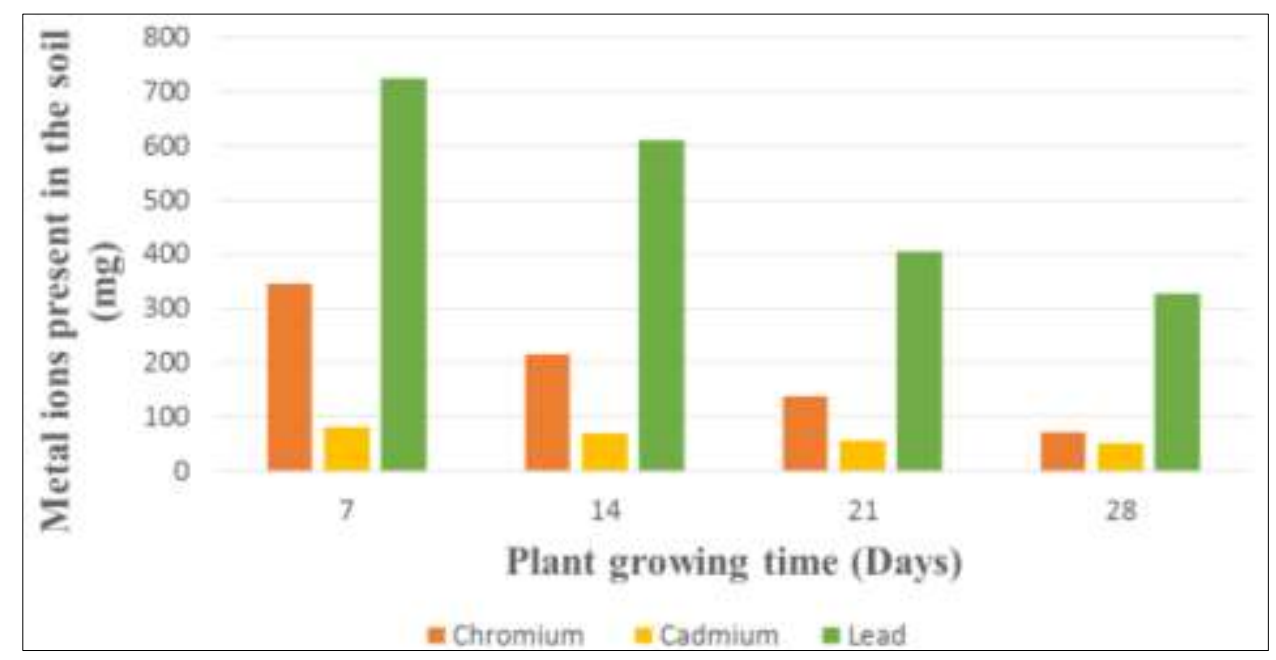

Fig 5: Phytoremediation of soil by Helianthus annuus in different days (Orekanti et al., 2019) ${ }^{[18]}$

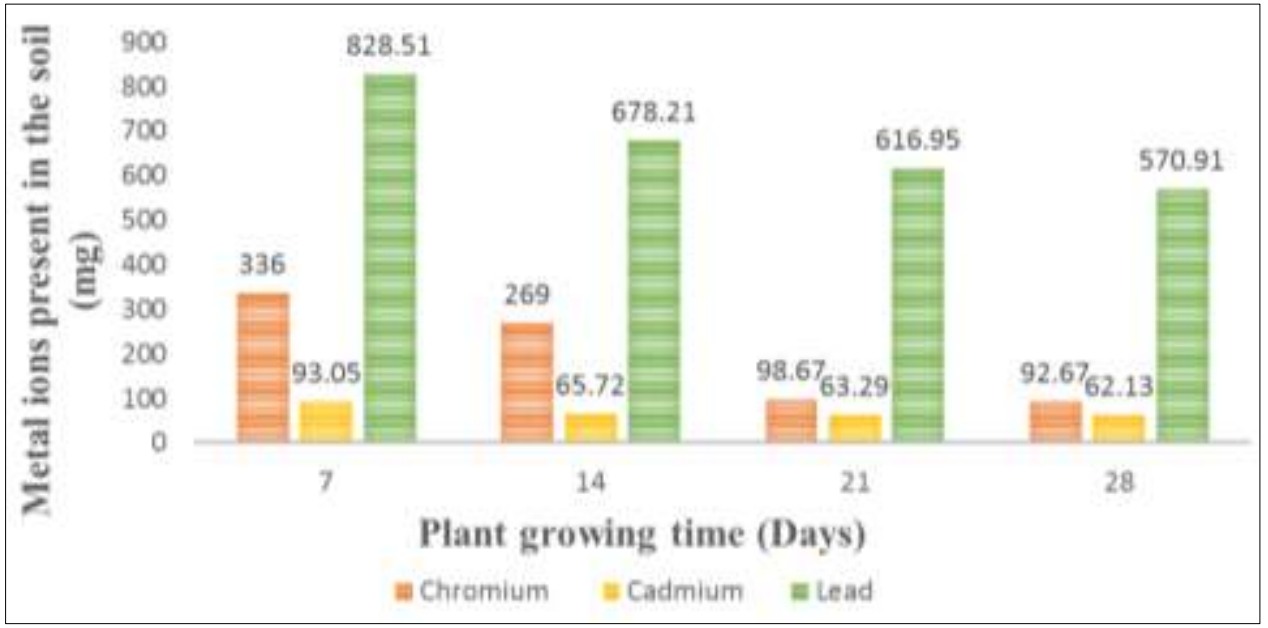

Fig 6: Phytoremediation of soil by Macrotylum uniflorum in different days (Orekanti et al., 2019) ${ }^{[18]}$

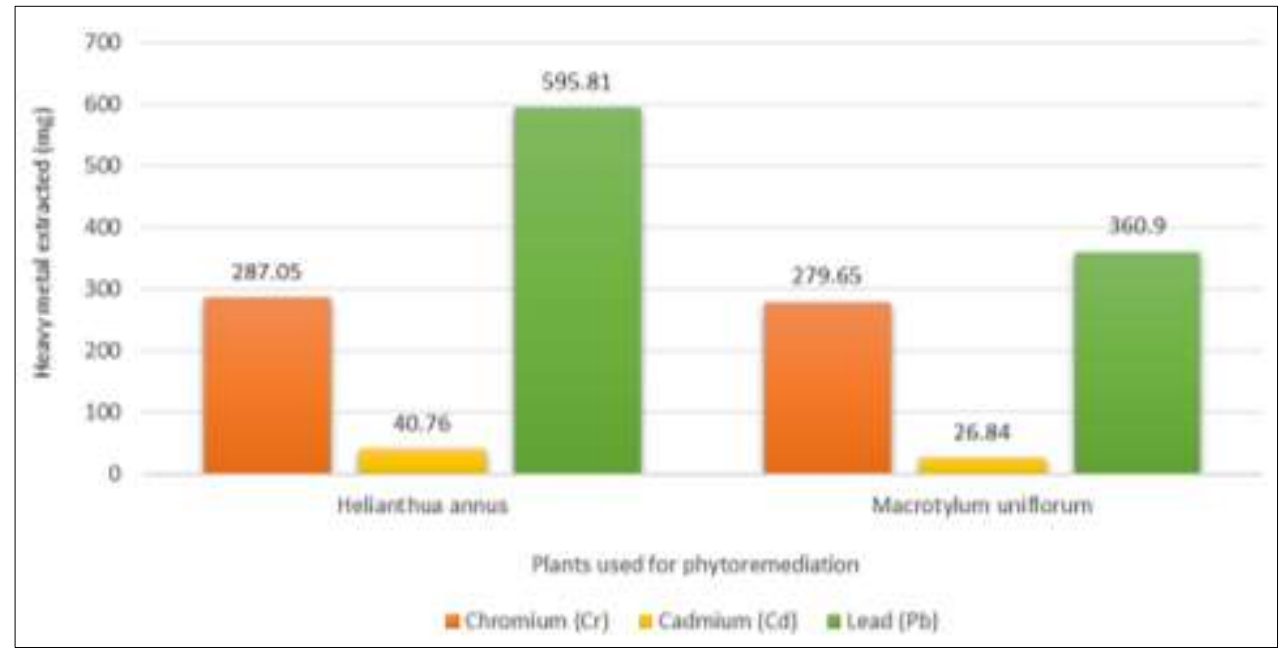

Fig 7: Extracted heavy metals from different phytoremediated plant tissues (Orekanti et al., 2019) ${ }^{[18]}$

Potential of duckweed (Lemna minor) for the phytoremediation of wastewater

The study was carried out to study the ability of duckweed (Lemna minor) in removing heavy metals from wastewater. One set of experimental containers, having three tubs, was arranged. Each experimental container was filled with $20 \mathrm{~L}$ wastewater and $200 \mathrm{~g}$ fresh weight of duckweed. Phytoextraction of zinc, copper, lead, iron, and nickel from landfill leachate by duckweed (L. minor) was investigated every 3 days over a period of 15 days. Heavy metal $(\mathrm{Zn}, \mathrm{Pb}$, $\mathrm{Fe}, \mathrm{Cu}$, and $\mathrm{Ni}$ ) contents were determined in both plant and leachate samples using the atomic absorption spectrophotometer (AAS). The concentration of different metals in the wastewater before and after phytoremediation is given in Table 6. Metal removal efficiency of Lemna minor was in the following order: $\mathrm{Cu}(91 \%)>\mathrm{Zn}(83 \%)>\mathrm{Pb}(78 \%)$ 
$>\mathrm{Fe}(77 \%)>\mathrm{Ni}(76 \%)$. Among 5 metals under study, the accumulation of copper in Lemna minor was the highest one. High removal efficiency and accumulation capacity of Lemna minor for heavy metals indicate its phytoremediation potential. This study provides a deep insight into the potential of duckweed (Lemna minor) to be used as a convenient and economically feasible method for the phytoremediation of metal-polluted aquatic environment on large-scale basis

Table 6: Heavy metal concentration of wastewater before and after phytoremediation experiment (Daud et al., 2018) ${ }^{[4]}$

\begin{tabular}{|c|c|c|c|}
\hline Parameters (mg/ L) & Before phytoremediation & After phytoremediation & Percentage reduction (\%) \\
\hline Zinc $(\mathrm{Zn})$ & 1.47 & $0.24 \pm 0.02^{*}$ & 73 \\
\hline Lead $(\mathrm{Pb})$ & 0.83 & $0.18 \pm 0.04^{*}$ & 91 \\
\hline Copper $(\mathrm{Cu})$ & 0.69 & $0.06 \pm 0.02^{* *}$ & 77 \\
\hline Iron $(\mathrm{Fe})$ & 1.17 & $0.26 \pm 0.03^{*}$ & 76 \\
\hline Nickel $(\mathrm{Ni})$ & 1.21 & $0.29 \pm 0.02^{*}$ & 78 \\
\hline
\end{tabular}

\section{Phytoremediation potential of jute in different} concentrations of copper contaminated soil

This research was carried out to examine the phytoremediation potential of Corchorus capsularis grown at different concentrations of $\mathrm{Cu}(0,100,200,300$, and $400 \mathrm{mg}$ $\mathrm{kg}^{-1}$ ) in a glass house environment. Soil as well as plant analysis was done to determine the copper uptake capacity of jute. The initial and final concentration of copper in the soil is given in Fig.8. The uptake and percentage removal efficiency was calculated using the formula-
Uptake of copper by jute $(\mathrm{mg} / \mathrm{kg})=\mathrm{C}_{0}-\mathrm{C}_{1}$ $\%$ Removal efficiency $=\left(\mathrm{C}_{0}-\mathrm{C}_{1} / \mathrm{C}_{0}\right) * 100$ where, $\mathrm{C}_{0}=$ Initial concentration of copper in soil $(\mathrm{mg} / \mathrm{kg})$ and $\mathrm{C}_{1}=$ Final concentration of copper in soil $(\mathrm{mg} / \mathrm{kg})$.

It was clear from Fig.9 that Corchurus capsularis can remove a large amounts of $\mathrm{Cu}$ from the soil, ranging 72-60\% of the $\mathrm{Cu}$ in $\mathrm{Cu}$-contaminated soil. The maximum $\mathrm{Cu}$ uptake ability of Corchorus capsularis was $251 \mathrm{mg} \mathrm{kg}^{-1} \mathrm{Cu}$ at $400 \mathrm{mg} \mathrm{kg}^{-1} \mathrm{Cu}$. The maximum recovery of $\mathrm{Cu}$ observed was at $100 \mathrm{mg} \mathrm{kg}^{-1}$ $\mathrm{Cu}(72 \%)$, followed by $200 \mathrm{mg} \mathrm{kg}^{-1} \mathrm{Cu}(71 \%), 300 \mathrm{mg} \mathrm{kg}^{-1}$ $\mathrm{Cu}(65 \%)$ and $400 \mathrm{mg} \mathrm{kg}^{-1} \mathrm{Cu}(60 \%)$.

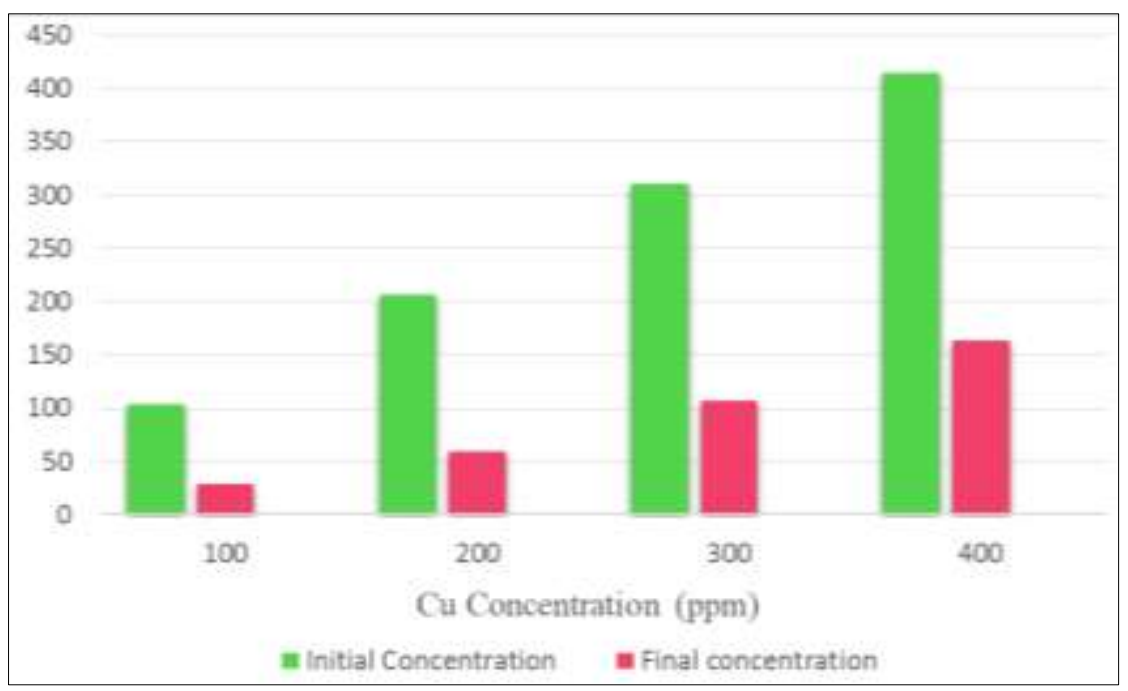

Fig 8: $\mathrm{Cu}$ concentration $(\mathrm{mg} / \mathrm{kg}$ ) in soil before and after harvest (Saleem et al., 2019)

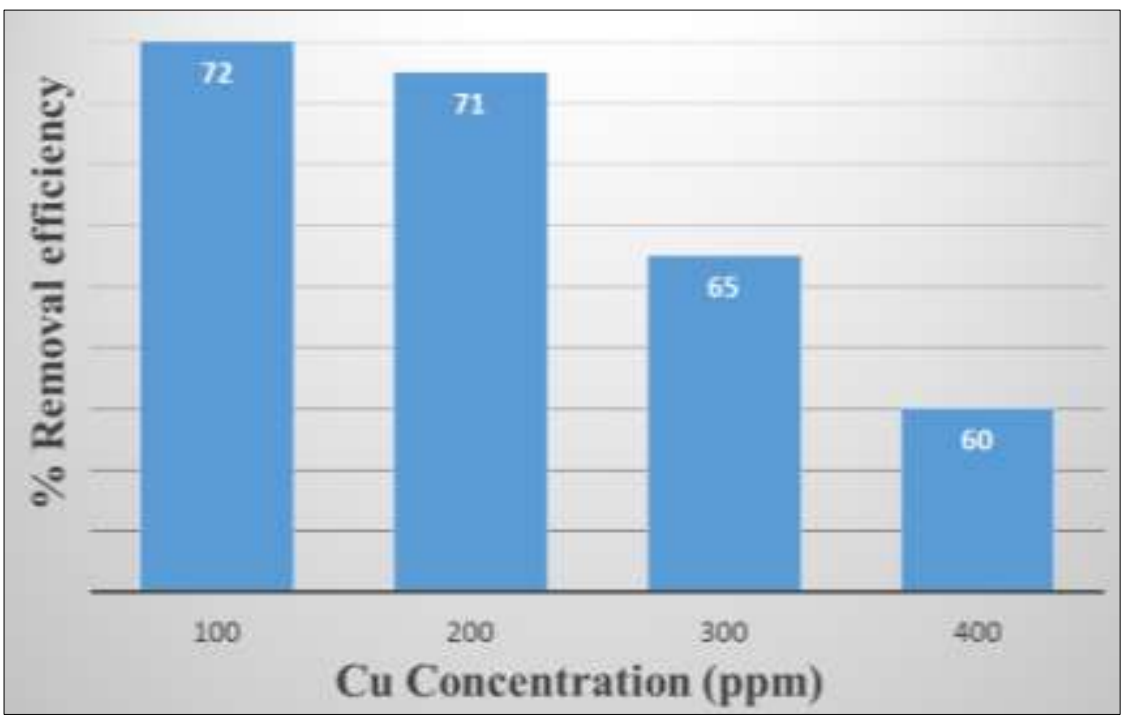

Fig 9: Uptake potential of copper (mg/kg) from soil by jute (Saleem et al., 2019) 


\section{Cadmium phytoremediation potential of Brassica juncea}

The study was conducted to test the cadmium phytoremediation potential of Brassica juncea from contaminated soil. Pot culture experiments were conducted using soil treated with Cadmium Chloride $\left[\mathrm{CdCl}_{2} \cdot \mathrm{H}_{2} \mathrm{O}\right]$. The cadmium chloride was uniformly mixed with air-dried soil sieved to $<2 \mathrm{~mm}$ and placed in pots $(4 \mathrm{~kg})$. The final soil concentration of $\mathrm{CdCl}_{2}$ was 25, 50, 100, 200 and $400 \mathrm{mg}$ per $\mathrm{kg}$ soil, respectively. Cadmium concentrations in the root, shoot and leaf tissues were estimated by atomic absorption spectroscopy. Table 7 depicts the $\mathrm{Cd}$ accumulation patterns of root, shoot and leaf of Brassica juncea after 21 days of exposure to different doses of $\mathrm{CdCl}_{2}$. For all the doses, shoot and leaf $\mathrm{Cd}$ accumulations were more than root $\mathrm{Cd}$ accumulation, except at $400 \mathrm{mg} \mathrm{Kg}^{-1}$ dose, where the root $\mathrm{Cd}$ (5415.6 $\mu \mathrm{g} \mathrm{g}^{-1}$ dry wt.) was higher than shoot $\left(3530 \mu \mathrm{g} \mathrm{g}^{-1}\right.$ dry wt.) and leaf (2603.3 $\mu \mathrm{g} \mathrm{g}^{-1}$ dry wt.) Cd concentration.
The maximum shoot and root $\mathrm{Cd}$ accumulation was at $200 \mathrm{mg}$ $\mathrm{kg}^{-1} \mathrm{Cd}$ at 10791 and $9602 \mu \mathrm{g} \mathrm{g}^{-1}$ dry wt., respectively and the maximum leaf $\mathrm{Cd}$ accumulation was $10071.6 \mu \mathrm{g} \mathrm{g}^{-1}$ dry wt. at $100 \mathrm{mg} \mathrm{Kg}^{-1} \mathrm{Cd}$. The plants in the present investigation survived at $400 \mathrm{mg} \mathrm{kg}^{-1} \mathrm{Cd}$, which indicated high $\mathrm{Cd}$ tolerance of this plant. However, at this dose, the root accumulated more $\mathrm{Cd}$ as compared to aerial parts, which indicated an exclusion strategy (Baker, 1981) that is change in soil $\mathrm{pH}$, redox potential, rhizosphere chemistry and cadmium bioavailability depends on it, restriction of $\mathrm{Cd}$ transport from root towards aerial parts via xylem sap flow. Therefore, the plant can be recommended as cadmium hyperaccumulator. This plant can thus be recommended for phytoremediation purposes in India, as they are abundant, can grow well without fertilizer, has quick growth, high biomass, less harvest time, and high $\mathrm{Cd}$ tolerance (up to $400 \mathrm{mg} \mathrm{Kg}{ }^{-1}$ ) without showing much signs of toxicity.

Table 7: Cadmium concentration in different plant parts (roots, shoots and leaves) of Brassica juncea (Goswami and Das, 2015) ${ }^{\text {[7] }}$

\begin{tabular}{|c|c|c|c|}
\hline $\left.\mathbf{C d C l}_{\mathbf{2}} \mathbf{( m g} / \mathbf{k g}\right)$ & Root $(\boldsymbol{\mu g} / \mathbf{g}$ dry wt.) & Shoot $(\boldsymbol{\mu g} / \mathbf{g}$ dry wt.) & Leaves $(\boldsymbol{\mu g} / \mathbf{g} \mathbf{~ d r y}$ wt.) \\
\hline 25 & $2123.6 \pm 336.04$ & $2950.3 \pm 698.05$ & $2953.6 \pm 85.11$ \\
\hline 50 & $4346.0 \pm 439.98^{*}$ & $6525.33 \pm 233.03 * \mathrm{~b}$ & $6223 \pm 72.64 * \mathrm{~b}$ \\
\hline 100 & $8370.6 \pm 197.6^{*}$ & $10657.3 \pm 418.8 * \mathrm{c}$ & $10071.6 \pm 563.12 * \mathrm{c}$ \\
\hline 200 & $9602.0 \pm 229.67^{*}$ & $10791 \pm 195.24 * \mathrm{~d}$ & $9588 \pm 91.93 *$ \\
\hline 400 & $5415.6 \pm 352.32^{*}$ & $3530.3 \pm 502.6 \mathrm{e}$ & $2603.3 \pm 63.72 \mathrm{e}$ \\
\hline
\end{tabular}

Phytoremediation of copper and cadmium contaminated water by water hyacinth

The present study demonstrated the phytoremediation potential of water hyacinth Eichhornia crassipes, for the removal of copper $(\mathrm{Cu})$ and Cadmium $(\mathrm{Cd})$. Young plants of equal size were grown in tap water and supplemented with $0.35,0.70$ and $1.05 \mathrm{mg} / \mathrm{L}$ of $\mathrm{Cu}$ and $0.27,0.54$ and $0.81 \mathrm{mg} / \mathrm{L}$ of $\mathrm{Cd}$ individually for 25 days. The plant at all the concentrations used in the experiment removed approximately more than $90 \%$ of $\mathrm{Cu}$ and $\mathrm{Cd}$. High removal (>90\%) of copper and cadmium was observed after 25 days experiment. Thus, water hyacinth is an excellent phytoremediator of copper as well as cadmium.

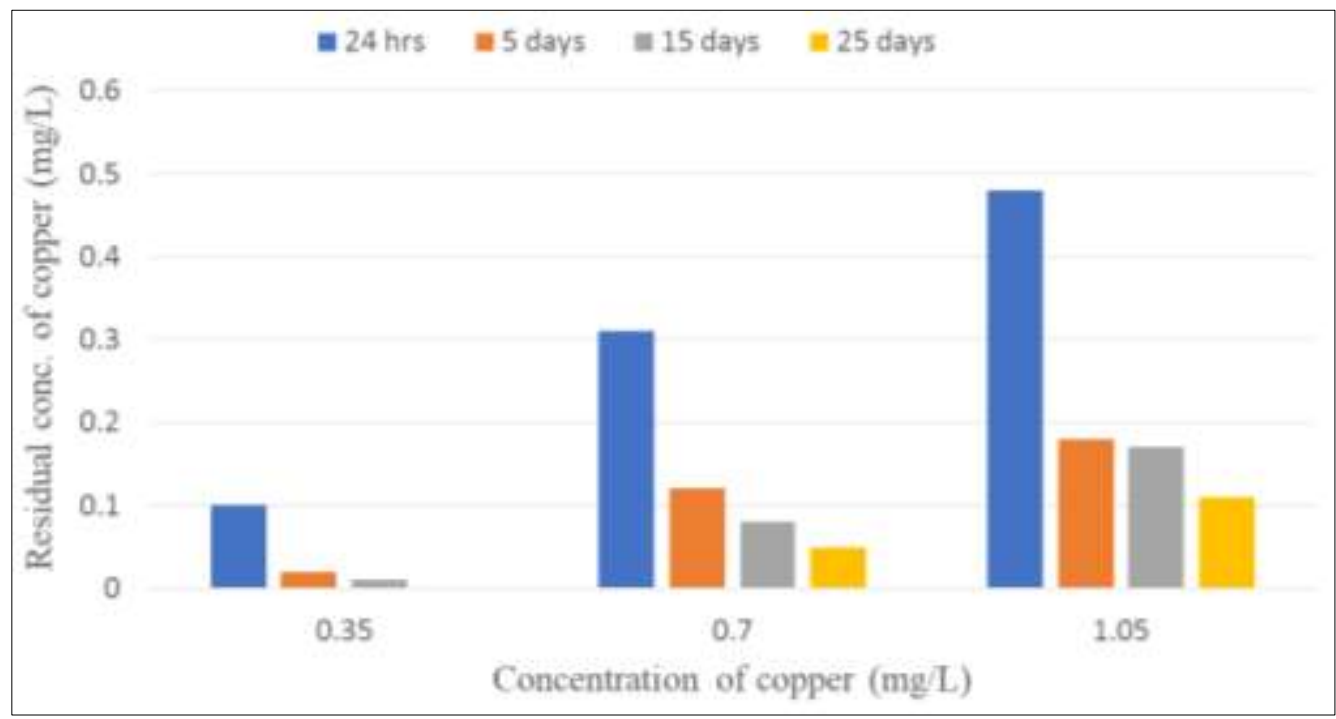

Fig 10: Residual concentration of copper in water after uptake by water hyacinth (Swain et al., 2014) ${ }^{[22]}$ 


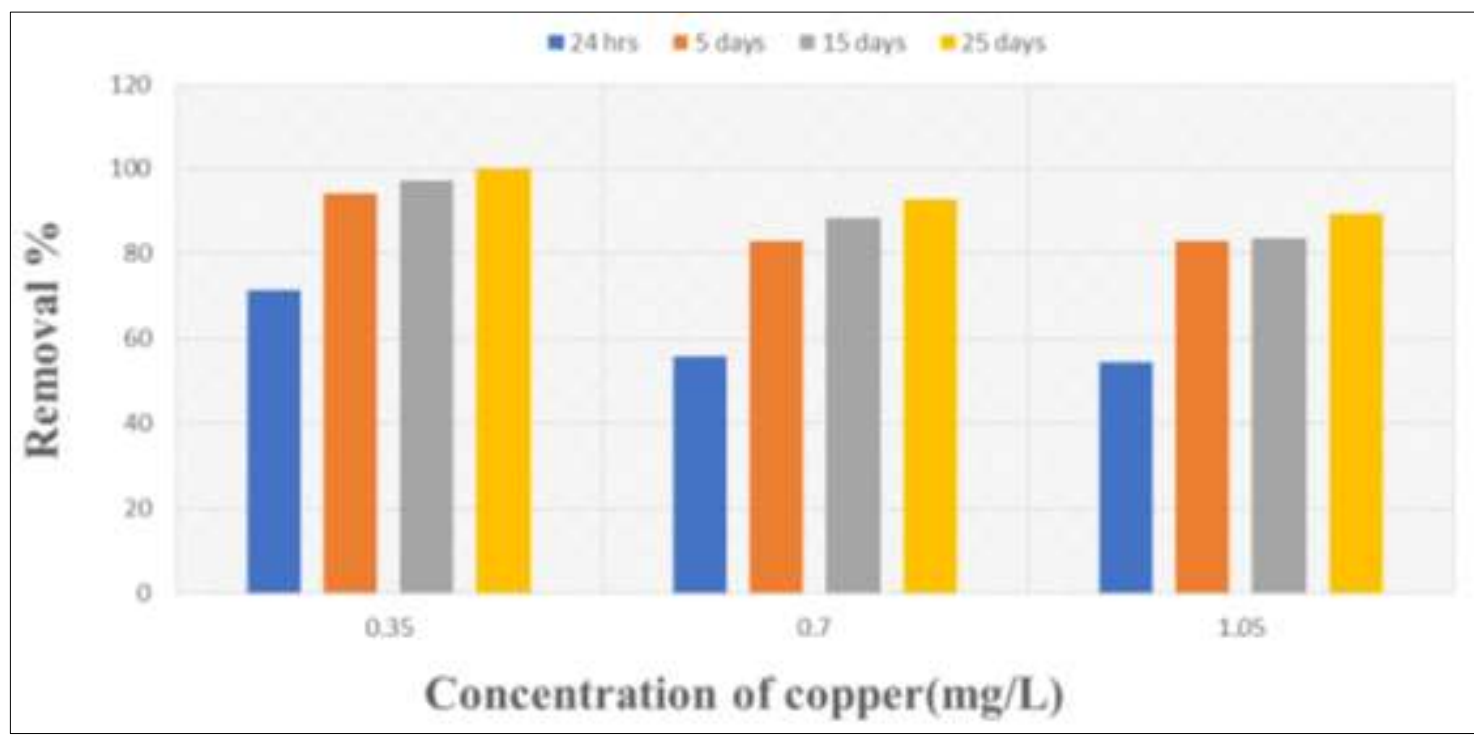

Fig 11: Copper removal \% by water hyacinth (Swain et al., 2014) ${ }^{[22]}$

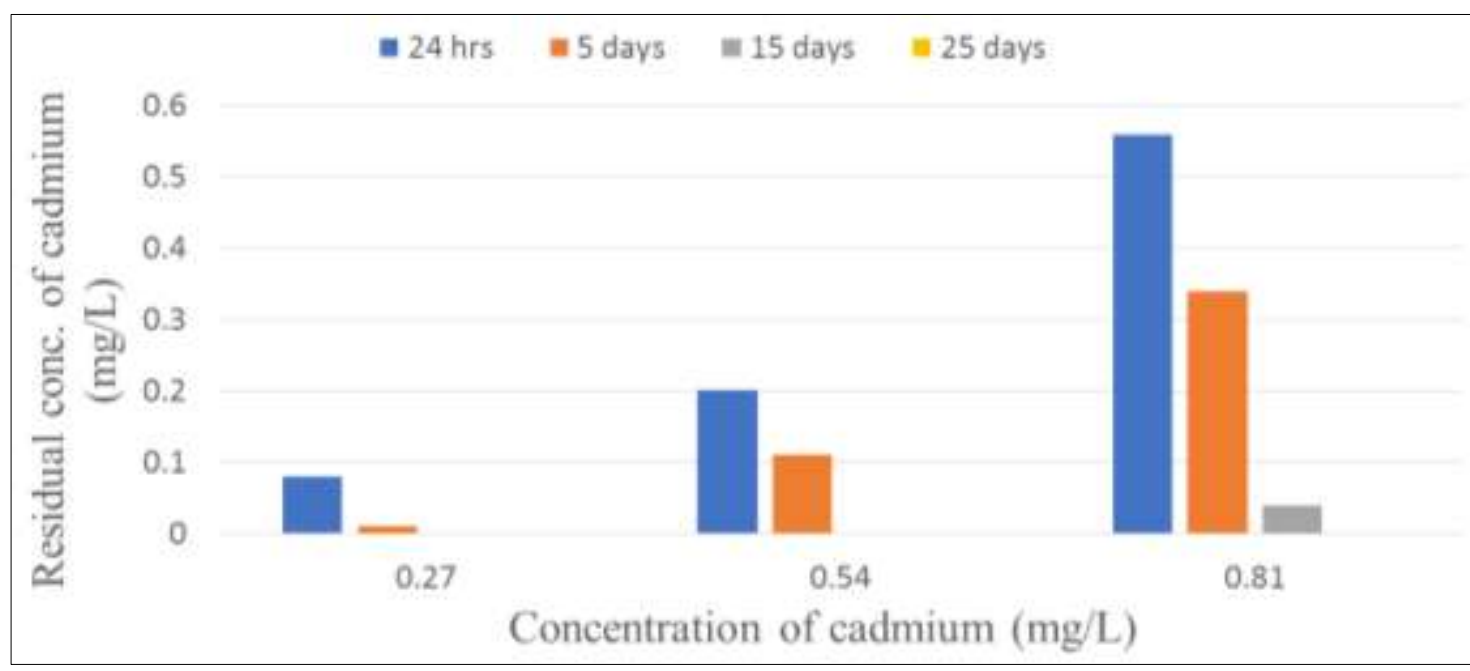

Fig 12: Residual concentration of cadmium in water after uptake by water hyacinth (Swain et al., 2014) ${ }^{\text {[22] }}$

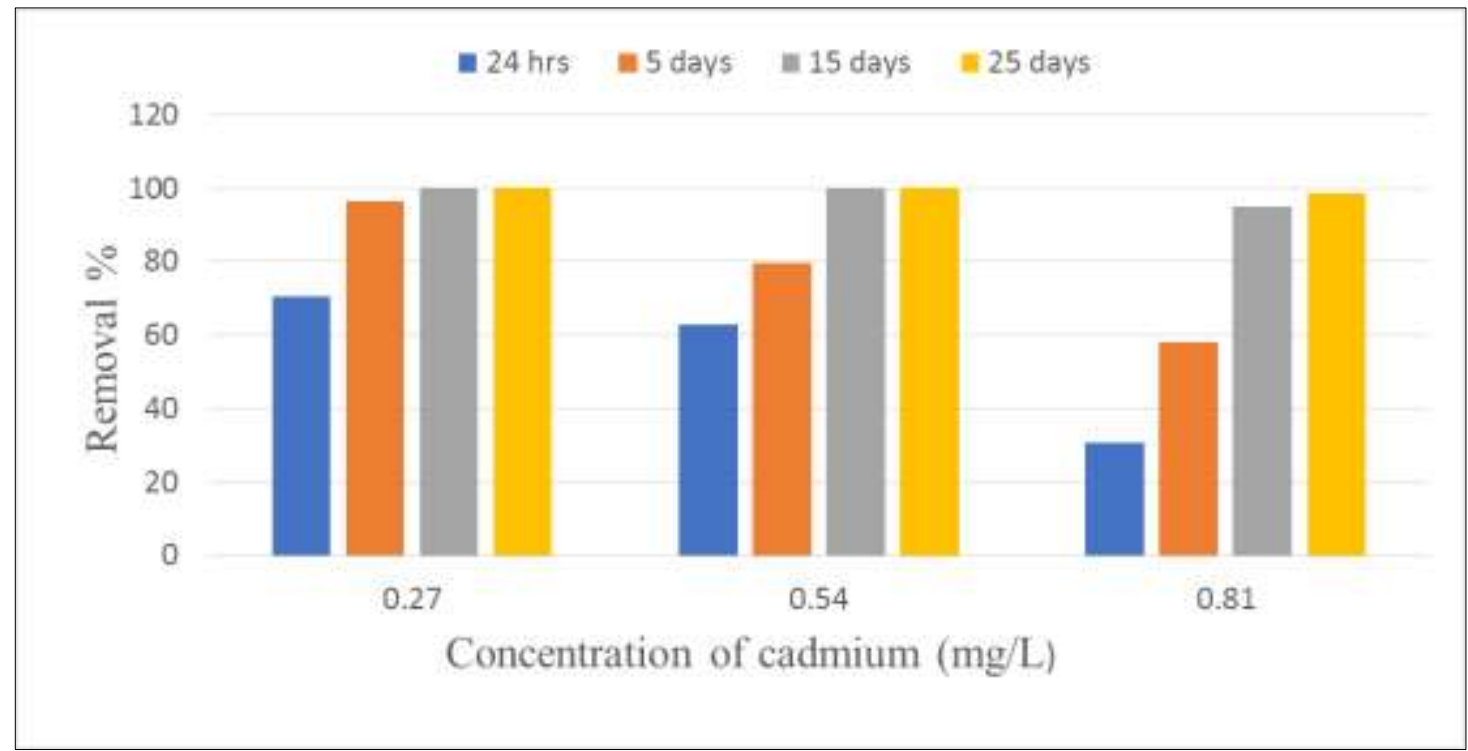

Fig 13: Cadmium removal \% by water hyacinth (Swain et al., 2014) ${ }^{[22]}$

Phytoremediation of heavy metal contaminated water using water lettuce

This study was done to investigate the potential of water lettuce (Pistia stratiotes) for removal of copper, iron and mercury $\left(\mathrm{Cu}^{2+}, \mathrm{Fe}^{3+}\right.$ and $\left.\mathrm{Hg}^{2+}\right)$ from heavy metal contaminated water amended at different concentration that 
are 5, 10 and $15 \mathrm{mg} \mathrm{L}^{-1}$. The contents of $\mathrm{Cu}^{2+}, \mathrm{Fe}^{3+}$ and $\mathrm{Hg}^{2+}$ were decreased from water after 32 days of experiment. The results showed that the highest removal of selected metals $\left(\mathrm{Cu}^{2+}: 53.20 \%, \mathrm{Fe}^{3+}: 83.20 \%\right.$ and $\left.\mathrm{Hg}^{2+}: 62.14 \%\right)$ by Pistia stratiotes was observed in $5 \mathrm{mg} \mathrm{L}^{-1}$ treatment (Fig.16). So, from this experiment it was concluded that water lettuce (Pistia stratiotes) can be used as a potential phytoremediator for copper, iron and mercury.

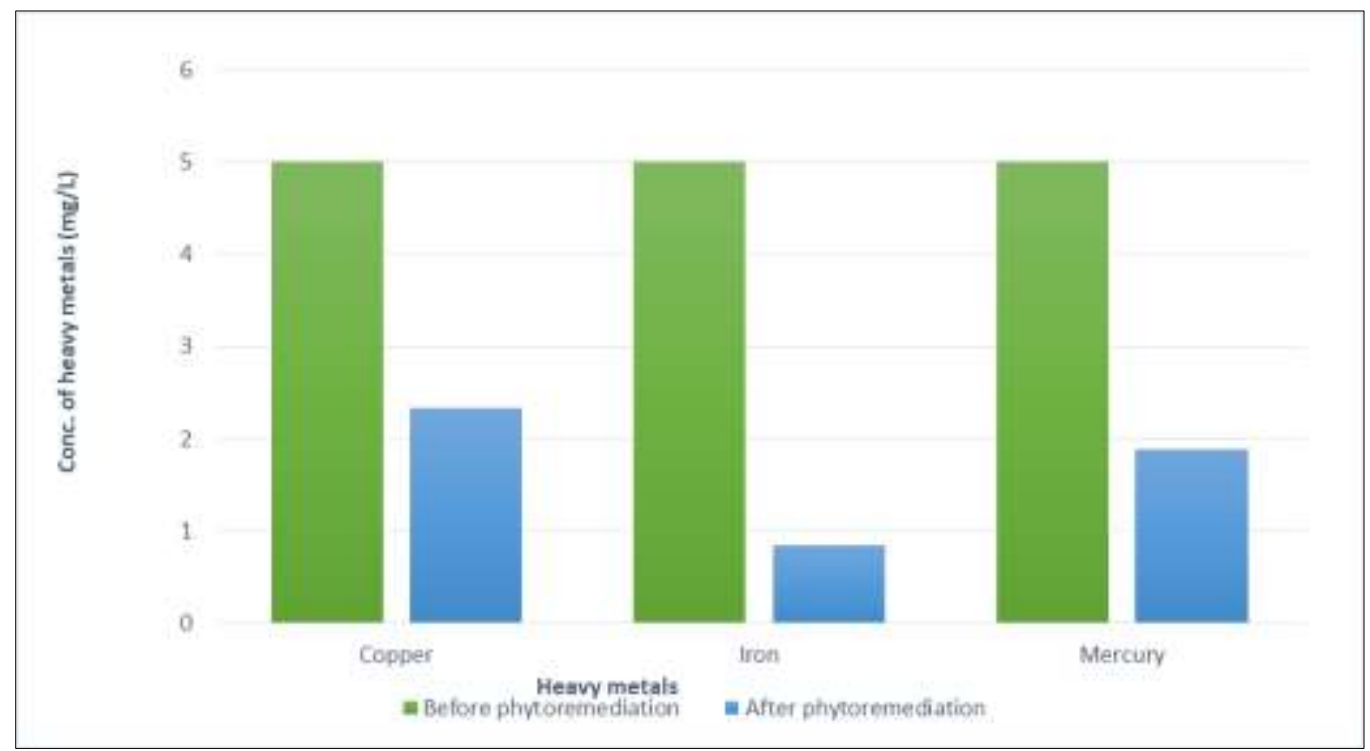

Fig 14: Concentration of heavy metals in water after 32 days of experiment in case $5 \mathrm{mg} / \mathrm{L}$ concentration of heavy metals (Kumar et al., 2019) [10]

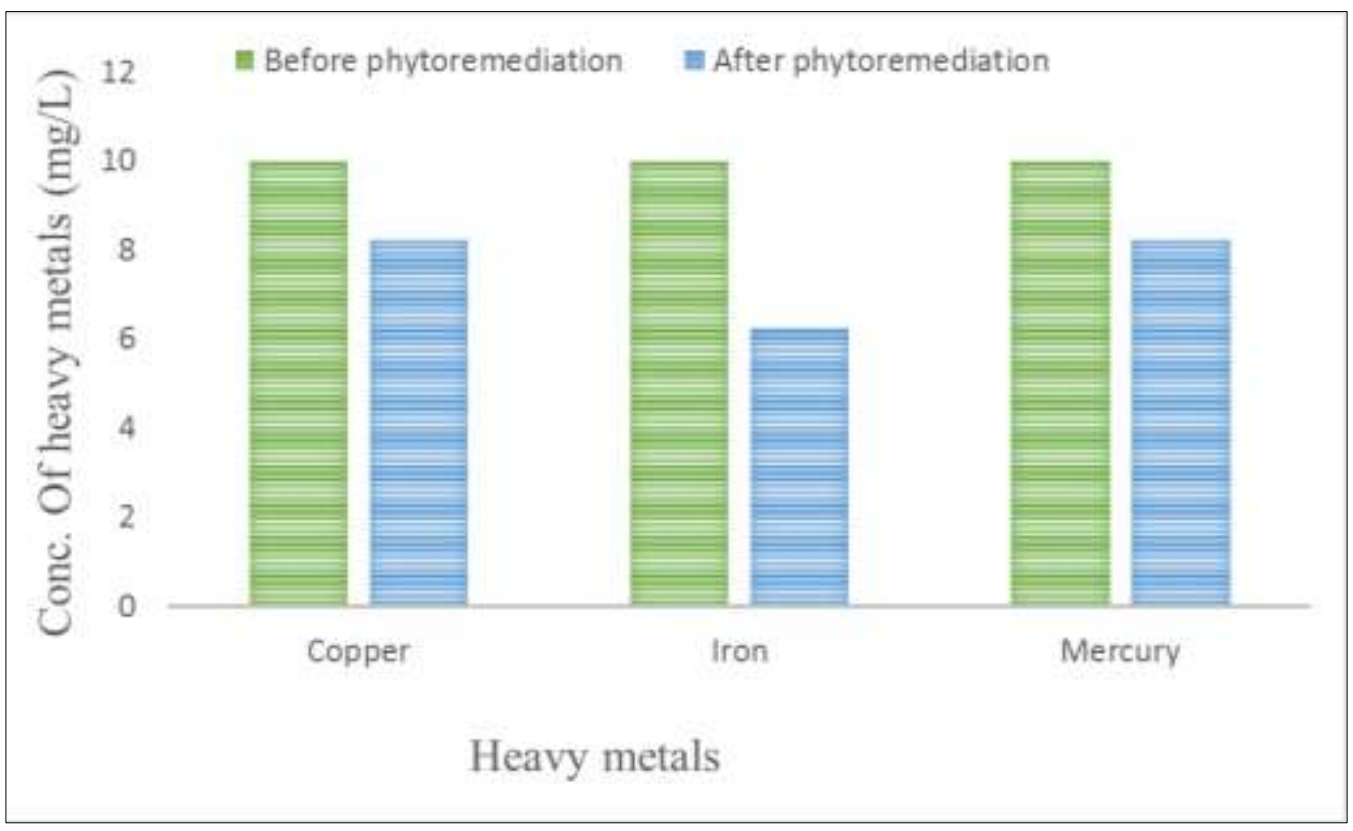

Fig 15: Concentration of heavy metals in water after 32 days of experiment in case $10 \mathrm{mg} / \mathrm{L}$ concentration of heavy metals (Kumar et al., 2019) [10] 


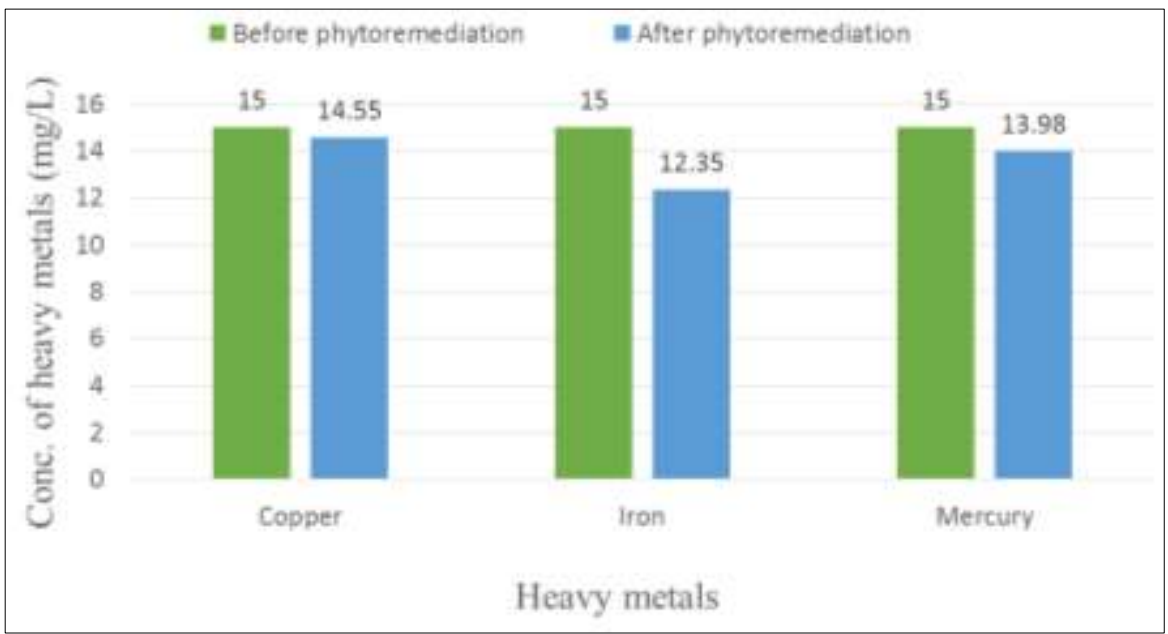

Fig 16: Concentration of heavy metals in water after 32 days of experiment in case 15mg/L concentration of heavy metals (Kumar et al., 2019) [10]

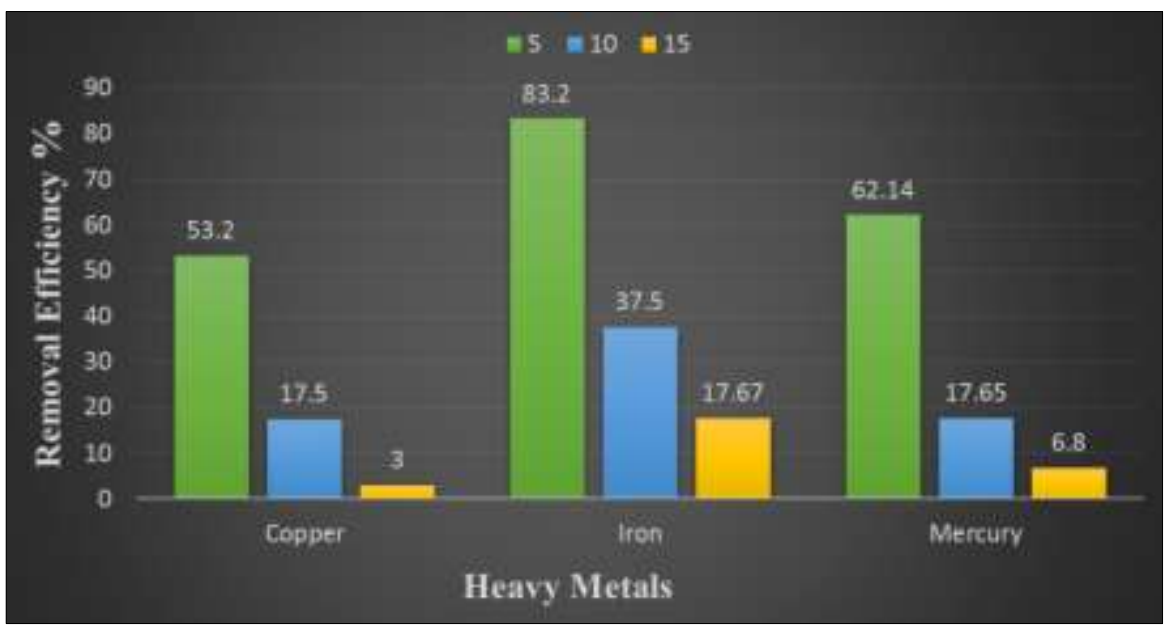

Fig 17: Percent removal efficiency of water lettuce (Kumar et al., 2019) ${ }^{[10]}$

\section{Phytoremediation of arsenic using Colocasia esculenta}

An experiment was conducted for the evaluation of arsenic accumulation by kachu (Colocasia esculenta) from different concentration of arsenic contaminated soil. Plants were grown on soil treated with different arsenic concentrations that are $\mathrm{A} 1 ; 500 \mathrm{mg} / \mathrm{kg}, \mathrm{A} 2 ; 1000 \mathrm{mg} / \mathrm{kg}$ and A3; $2000 \mathrm{mg} / \mathrm{kg}$. Kachu had a tendency to accumulate arsenic from soil at higher level. Total arsenic accumulation was $422.3 \mathrm{mg} / \mathrm{kg}(84.46 \%)$ in case of $500 \mathrm{mg} / \mathrm{kg}(75.17 \%), 751.7 \mathrm{mg} / \mathrm{kg}(48.67 \%)$ at $1000 \mathrm{mg} / \mathrm{kg}$ and $973.5 \mathrm{mg} / \mathrm{kg}$ at concentration of $2000 \mathrm{mg} / \mathrm{kg}$ arsenic contamination. Colocasia esculenta had a higher arsenic accumulating capability and hence could be recommended for phytoremediation of arsenic contaminated soils.

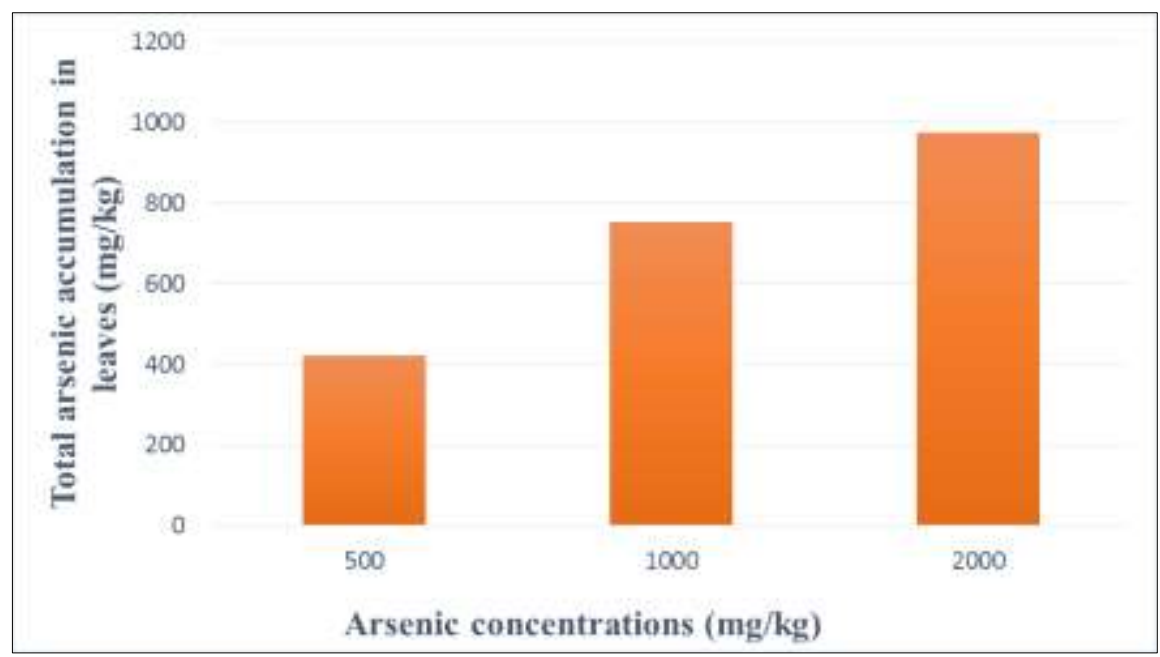

Fig 18: Accumulation of arsenic in leaves of Colocasia esculenta at different concentration (Manirul et al., 2015) ${ }^{[11]}$ 


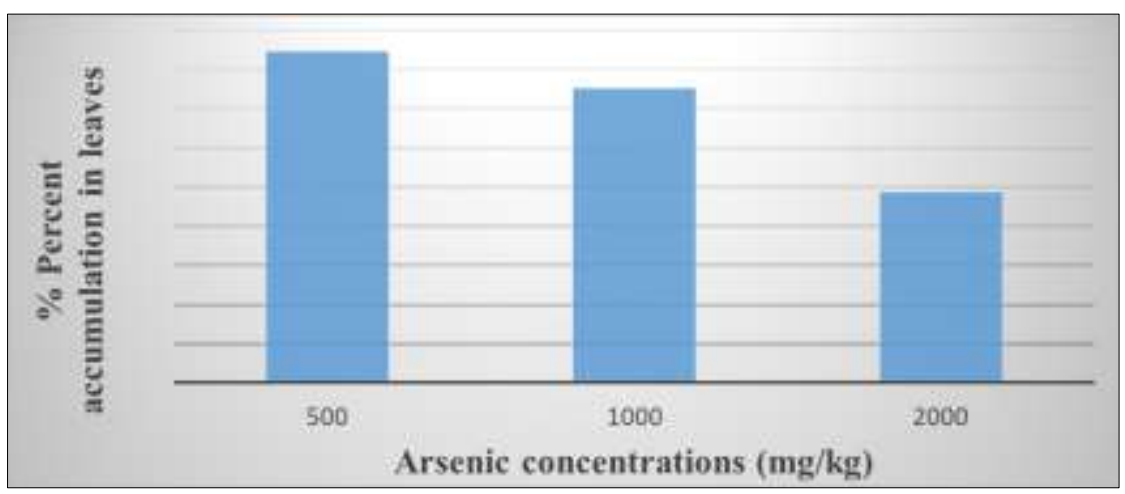

Fig 19: Percent accumulation of arsenic in leaves of Colocasia esculenta at different concentration (Manirul et al., 2015) ${ }^{[11]}$

Effectiveness of neem, cashew and mango trees in the uptake of heavy metals

This research was done to test the potential of mango, neem and cashew in phytoremediation of heavy metals present in the contaminated soil. The initial concentration of soil are given in the Table 8. Bark analysis of these three trees were done for determining the uptake efficiency of heavy metals. Concentration of heavy metals in bark of different trees were given in Fig. 20. The uptake efficiency of heavy metal under study of the three species are in the order of magnitude of Mango $>$ Cashew $>$ Neem (Fig. 21). It can be suggested that for better efficient clean-up especially where an area is polluted with copper, mango is best option for the uptake of such metal and cashew is the best option for uptake of lead from lead contaminated site.

Table 8: Initial concentration of heavy metal in soil (Ojekunle et al., 2015) ${ }^{[17]}$

\begin{tabular}{|c|c|}
\hline Heavy metals & Conc. in soil $(\mathbf{m g} / \mathbf{k g})$ \\
\hline Cadmium $(\mathrm{Cd})$ & 0.069 \\
\hline Lead $(\mathrm{Pb})$ & 2.959 \\
\hline Copper $(\mathrm{Cu})$ & 0.137 \\
\hline
\end{tabular}

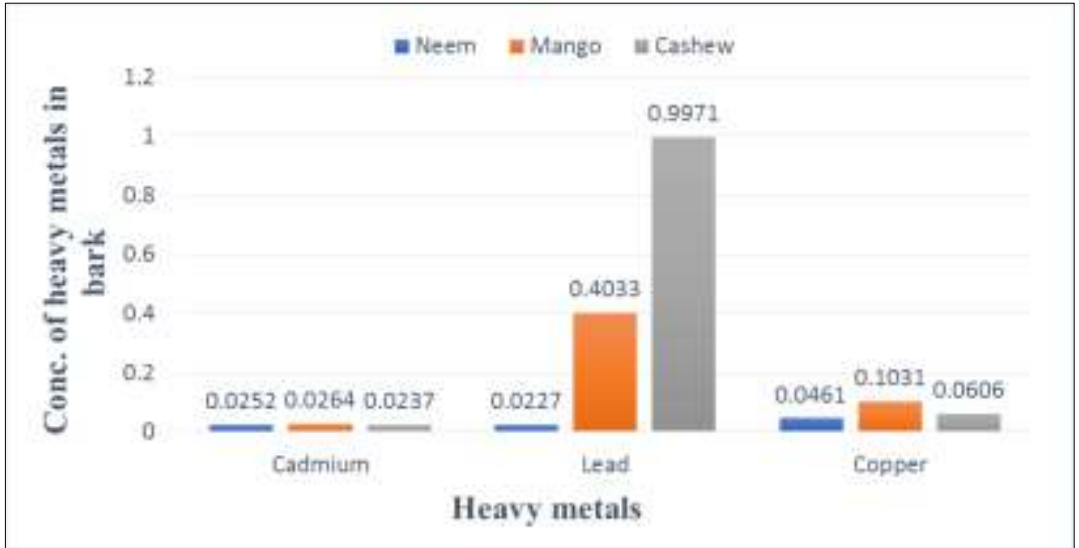

Fig 20: Concentration of heavy metals in bark of different plants (mg/kg) (Ojekunle et al., 2015) ${ }^{[17]}$

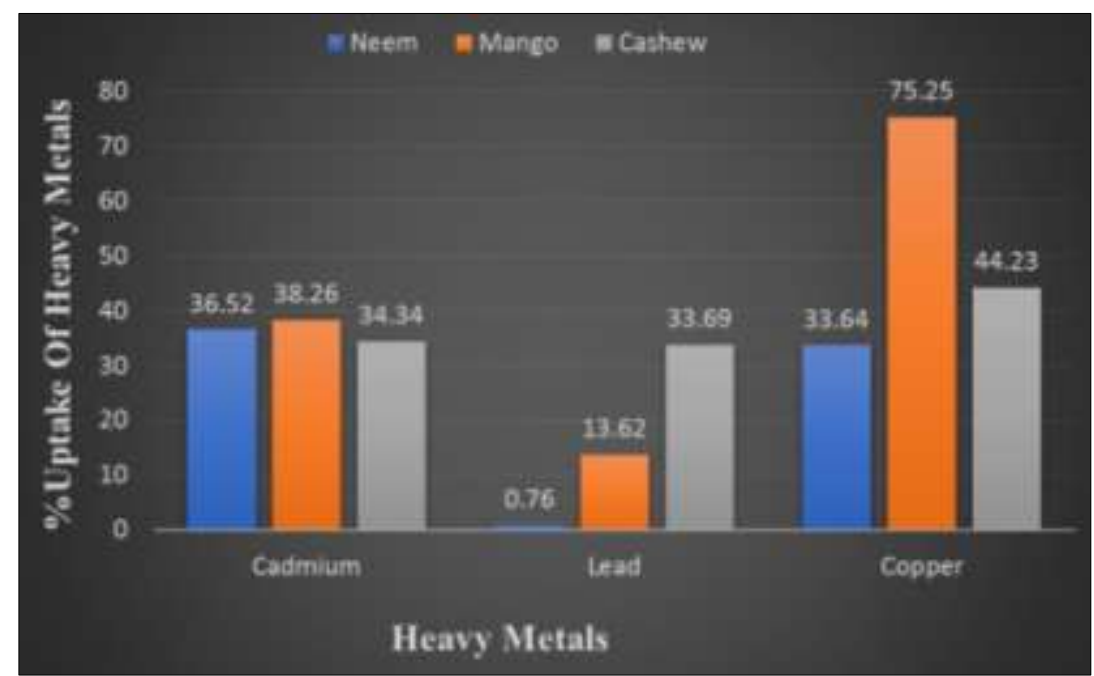

Fig 21: Comparison of the percent of the uptake of heavy metals by the bark of trees (Ojekunle et al., 2015) ${ }^{[17]}$

$$
\sim 849 \sim
$$




\section{Fate of plants used for phytoremediation}

The plants used for phytoremediation of heavy metal contaminated sites can be disposed in the following ways-

a) Pyrolysis: Pyrolysis decomposes material under anaerobic condition. The final products of pyrolysis are gases, organic liquids and charcoal. Gases are hydrogen, methane and carbon dioxide. These gases can be used for drying biomass which after grinding are transferred to the pyrolysis reactor.

b) Phytomining: In this process, the plants after harvesting are dried and burnt to convert it into ash form. The ash is called as 'bio-ore' which can be further used in smelting for extraction of metals.

c) Composting: Harvested biomass can be used in compost but as these contain heavy metals they should be treatd properly before using as a compost.

\section{Conclusion}

Heavy metal pollution is a global concern and a major threat worldwide. Phytoremediation is a remediation technology to clean up the contaminants from environment by using green plants. This technique applied various mechanisms, which include heavy metals uptake (phytoextraction), breakdown and transformation of heavy metals (phytodegradation), emission in atmosphere (phytovolatilization) and their stabilization in the root system (phytostabilization). More extensive research under field conditions is required for selection of the most useful plants, to increase the understanding of the metabolic activities involved in heavy metal tolerance in hyper-accumulator plants to unlock new directions for phytoremediation. Several methods of crop disposal have been described but there is lack of sufficient data on any of them. Future experiments should concentrate on development methods of disposal of plants used in phytoremediation.

\section{References}

1. Ali H, Khan E, Sajad MA. Phytoremediation of heavy metals concepts and applications. Chemosphere 2013; 91:869-881.

2. Cunningham SD, Berti WR, Huang JW. Phytoremediation of contaminated soils. Trends in Biotechnology 1995;13:393-397.

3. Das P, Datta R, Makris KC, Sarkar D. Vetiver grass is capable of removing TNT from soil in the presence of urea. Environmental Pollution 2010;158:1980-1983.

4. Daud MK, Ali S, Abbas Z, Zaheer IE, Riaz MA, Malik A et al. Potential of duckweed (Lemna minor) for the phytoremediation of landfill leachate. Journal of Chemistry 2018,1-9.

5. Etim E. Phytoremediation and its mechanisms: a review. International Journal of Environment and Bioenergy 2012;2:120-136.

6. Gerhardt KE, Huang XD, Glick BR, Bruce M, Greenberg BM. Phytoremediation and rhizoremediation of organic soil contaminants: potential and challenges. Plant Science 2009; 176:20-30.

7. Goswami S, Das S. A study on cadmium phytoremediation potential of Indian mustard, Brassica juncea. International Journal of Phytoremediation 2015;17:583-588.

8. Hannink N, Subramanian N, Rosser SJ, Basran A, Murray JAH, Shanks JV. Enhanced transformation of TNT by tobacco plants expressing a bacterial nitroreductase. International Journal of Phytoremediation 2007;9:385-401.
9. Karami A, Shamsuddin ZH. Phytoremediation of heavy metals with several efficiency enhancer methods. African Journal of Biotechnology 2010;9:3689-3698.

10. Kumar V, Singh J, Saini A, Kumar P. Phytoremediation of copper, iron and mercury from aqueous solution by water lettuce (Pistia stratiotes L.). Environmental Sustainability 2019;2:55-65.

11. Manirul MI, Mayda U, Mehraj H, Shiam IH, Jamal Uddin AFM. Evaluation of arsenic accumulation by Colocasia esculenta (Kochu) from soil. Journal of Soil and Nature 2015;8:1-4.

12. Mendez MO, Maier RM. Phytostabilization of mine tailings in arid and semiarid environments-an emerging remediation technology. Environment Health Perspectives 2008;116:278-283.

13. Misra S, Gedamu L. Heavy metal tolerant transgenic Brassica napus L. and Nicotiana tabacum L. plants. Theoretical and Applied Genetics 1989;78:161-168.

14. Mokhtar H, Morad N, Fizri FFA. Phytoaccumulation of copper from aqueous solutions using Eichhornia crassipes and Centella asiatica. International Journal of Environmental Science and Development 2011;2:205210.

15. Muthusaravanan S, Sivarajasekar N, Vivek J, Paramasivan T, Naushad M, Prakashmaran J et al. Phytoremediation of heavy metals: mechanisms, methods and enhancements. Environmental Chemistry Letters 2018;16:1339-1359.

16. Nagajyoti PC, Lee KD, Sreekanth TVM. Heavy metals, occurrence and toxicity for plants: a review. Environmental Chemistry Letters 2010;8:199-216.

17. Ojekunle Z, Ubani D, Sangowusi R. Effectiveness of neem, cashew and mango trees in the uptake of heavy metals in mechanic village, Nigeria. African Journal of Environmental Science And Technology 2015;9:136-142.

18. Orekanti E, Muni K, Devarajan S. Pilot Study on Phytoremediation of Contaminated Soils with Different Plant Species. Journal of Hazardous, Toxic, And Radioactive Waste 2019;23:1-7.

19. Rouch DA, Lee BTO, Morby AP. Understanding cellular responses to toxic agents: a model for mechanism-choice in bacterial metal resistance. Journal of Industrial Microbiology 1995;14:132-141.

20. Saleem M, Fahad S, Khan S, Ahmar S, Ullah Khan M, Rehman M et al. Morpho-physiological traits, gaseous exchange attributes, and phytoremediation potential of jute (Corchorus capsularis L.) grown in different concentrations of copper-contaminated soil. Ecotoxicology and Environmental Safety 2020;189:1-11.

21. Subhasini V, Swamy AVVS. Phytoremediation of cadmium and chromium contaminated soils by Cyperus Rotundus L. American International Journal of Research in Science, Technology and Enginerring and Mathematics 2014;6:97-101.

22. Swain G, Adhikari S, Mohanty P. Phytoremediation of Copper and Cadmium from Water Using Water Hyacinth, Eichhornia Crassipes. International Journal of Agricultural Science and Technology 2014;2:1-7.

23. Terry N, Zayed AM, de Souza MP, Tarun AS. Selenium in higher plants. Annual Review of Plant Physiology and Plant Molecular Biology 2000;51:401-432.

24. Wang HQ, Zhao Q, Zeng DH, Hu YL, Yu ZY. Remediation of a Magnesium-Contaminated Soil by Chemical Amendments and Leaching. Land Degradation and Development 2015;26:613-619. 